Egyptian Journal of Archaeological and Restoration Studies
An international peer-reviewed journal published bi-annually
wwars.ejars.sohag-univ.edu.eg

Original article

\title{
TYPOLOGY OF THE OTTOMAN MAUSOLEUMS IN RHODES IN THE LIGHT OF THE REMAINING TYPES IN CEMETERY OF MURAD RE'IS
}

\author{
Abdel Wahab, M. \\ Islamic Archaeology dept., Faculty of Archaeology, Fayoum Univ., Fayoum, Egypt \\ E-mail address:maa02@fayoum.edu.eg
}

\begin{tabular}{ll}
\hline Article info. & EJARS - Vol. 10 (1) - June 2020: $87-101$ \\
\hline Article history: & Abstract: \\
Received: $15 / 11 / 2019$ & The Greek cities hold a broad base of the religious, civil, war, \\
Accepted: $21 / 4 / 2020$ & educational, commercial, and funeral architectural styles. Thus, it \\
is a good opportunity for the researchers in Islamic architecture \\
and civilization, in general, and the Ottoman, in particular, to \\
bridge many historical and architectural gaps. The researchers \\
have neglected and disregarded the monuments of the Ottoman \\
Empire in Europe, especially after the collapse of the Ottoman \\
Empire in the European part. It was deliberate neglect inspired by \\
racism in some European countries. They sometimes tended to \\
carelessness or direct destruction. Consequently, less than (10 \\
\%) of the original monuments have survived, as shown in the \\
books of travelers and statistics by the Ottoman authorities. The \\
remaining monuments, even a few, are important for understand- \\
ing and identifying the characteristics of Ottoman architecture and \\
the arts in the European cities, especially Rhodes. Fortunately, \\
this Island still holds hundreds of Ottoman monuments. The mau- \\
soleums and cemeteries are among the most significant resources \\
in identifying the Ottoman architectural styles and patterns in \\
Rhodes. They help form a complete picture, not only architect- \\
urally and technically, but also demographically as well as nature, \\
Rhodes \\
names, titles, and occupations of the Ottomans at that time.
\end{tabular}

\section{Introduction}

The survival of such architectural styles has motivated scholars and authors, especially Kiel. M [1], to adopt a positive attitude regarding reinvestigating the monuments of the Ottoman Empire [2]. This helps unveil many details and study history . Such studies have highlighted the cultural, architectural, social, intellectual, administrative and other aspects regarding the Ottoman administration of the vast land it controlled. The Ottoman governments tried to modify these aspects to be part of the Ottoman ideology based on an Islamic concepts as well as a political one that they are the heirs of the Byzantine Empire [3].
The author was motivated to conduct the study by doing archaeological and architectural documentation to maintain the OttomanIslamic history and monuments at that part of Europe via their writings, inscriptions, ornaments, as well as the relevant documents and awqaf (endowments) that ensured fulfilling the jobs defined by the founder. Additionally, he hopes that the study paves the way to raise the awareness of the importance of an era that lasted for more than four centuries and resulted in many architectural and cultural monuments, which affected the European cities. The study focuses on the remaining Ottoman mausoleums in 
the cemetery of Murad Re'is who was buried in front of his mosque in the same place $^{(a)}$. Murad Re'is or the elder (Turkish: Koca Murat Re'is (1534-1609) was considered one of the most important Barbary corsairs in the Ottoman Empire. He was born into an Albanian family in Albania or Rhodes. At a very young age, he joined Hayreddin Barbarosa to Constantinopole. Then, he was appointed to take command of the Ottoman fleet. While Murad Re'is is known in Ottoman history as a corsair and naval commander, he has acquired the sanctity of a saint among the Muslim faithful [4]. The growth of the cemetery dates from the death of Murad Re'is in 1609 and the founding of his mausoleum. It should be noted that this cemetery was dedicated to the high-ranking of Ottoman officials and Crimean Khans; for example, there were three of Kanuni Suleiman's commanders, i.e. Borazan Ali Dede, Abdulcelel Bey, and Cafer Bey were buried there [5]. These commanders took part in the siege of the Island (1522-1523). Hence, it was used as cemetery before the deathof Murad Re'is in 1609. Some scholars argued that the area was used as a cemetery for Muslims from the early Arab conquest in $53 \mathrm{H} / 672$ 3 [4]. This region was used as a cemetery for Muslims since 53/672-3 or before. The Muslims conquered the Island twice. First, they did so in $28 \mathrm{H} / 657$, but soon they got out of it before Janada bin Abi Umayya re-conqueredit in $58 \mathrm{H} / 678$. Moreover, the Island of Rhodes became an important base for the Islamic navy. However, the Muslims left it before they returned during the reign of Caliph Harun al-Rashid [6]. The Museum of Walterspreserves the map of Perry Re'is, which dates back to $1522 \mathrm{AD}$, during which the Ottomans besieged the Island. It showsa mosque in the same location of the present cemetery outside the fortifications of the castle, fig. (1-a) [7]. This map (1525) confirms that the location was used as acemetery before the cupture of the city by Sultan Sulyman. Currently, there are about two hundred grave stelai in Murad Re'is cemetery. Most of them were members of the Ottoman civil, military, and religious aristocracy, as well astheir families. They represent only a fraction of the members of the Ott-oman ruling class who were buried there over four hundred years [5]. On the contrary, in the cemetery of Gani Ahmed, a simple distance from Murad Re'is, the remaining inscriptions indicate the low social level of those buried there. The majority of graves and gravestones belong to Ottoman officials and Crimean Khans ${ }^{(\mathrm{b})}$ buried there. Many of them were exiled or exiled and executed in the Island, such as Crimean Khan Sahin Giray (1640), Sadr-I a'zam Gurcu Yusuf pasha (D. 1127/1718), Sari 'Abdullah Pasha (D. 1147/1734), Abdul kerim pasha (D. 1175/1761), and Sadr-I a'zam Kara Ibrahim Pasha (D. 1098/1687) $[4,5]$. However, many remaining mausoleums belong to some Ottoman officials who were exiled to Rhodes and died there, fig. (1-b), including Crimean Khan Fetih Giray I (1595), (D. 1074/1663), Crimean Khan Saadet Han-I II(D. 1106/ 1694), Crimean Khan Canbeg Giray (D. 1046/1636), Sadr-I a'zam Mehemt Rami Pasha (D. 1119/ 1707), Shah Safi Mirza II (D. 1169/1756), Sencar Havvas Bey (D. 1314/1896), and Mehmed Radif Pasha (D. 1323/1905). These are only the names whose shrines still appear in the cemetery from among the list mentioned by Rodoslu [5]. Such cemetery represents an important aspect and an architectural design that was the basis of architecture in most Islamic periods [8]. Because of being the final destination of the owner, he was always interested in its preparation in his lifetime to be commemorated in this world and to get a reward in the hereafter. Many establishments were attached to theses mausoleums, including religious, charity...etc. Therefore, many documents were dedicated to the endowment of mausoleums and their charity facilities to revive the rituals and be a feature of that era [4]. 

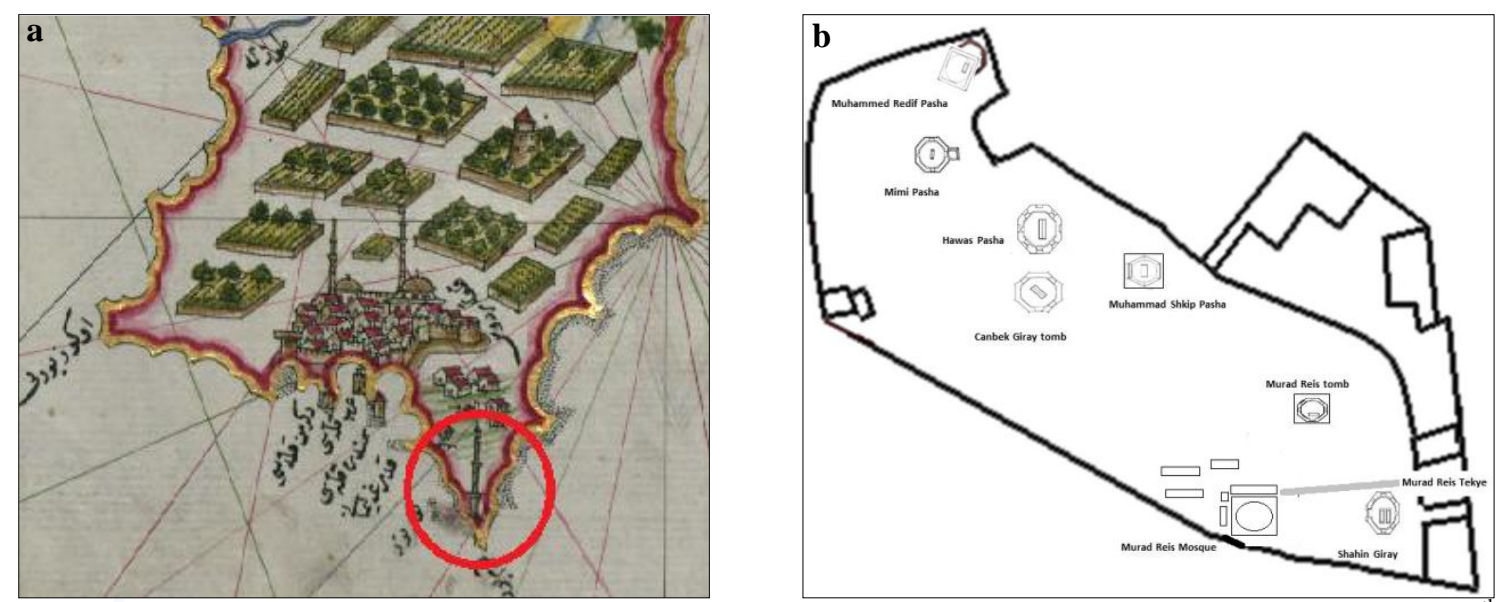

Figure. (1) Shows a. the northern tip of Rhodes Island and the location of the muslims' cemetery, from a $17^{\text {th }}$ A copy of Piri Re'is' south-oriented map made in 1525 in the Walter Art Library Collection, $\underline{\mathbf{b}}$. the distribution of the Ottoman mausoleums in the cemetery of Murad Re'is.

\section{Types of the Ottoman Mausoleums in Rhodes}

In the beginning, the Ottomans used to bury their dead in the cemetery of Murad Re'is to the northwest of the city, where his mosque and cemetery were established. This cemetery was dedicated to the Ottoman statesmen and military, official and high ranking members of Ottoman society. The other cemetery was the cemetery of Gani Ahmed to the east, next to the tombs of the Jews, Orthodoxies, and Catholics looking over the sea, fig. (2-a) [9]. Many nominations were used for the building on the tomb including, but not limited to, grave, cemetery, mausoleum, and dome. Moreover, the Ottomans adopted similar nominations. For example, they used the tomb and the mausoleum to refer to the graves of statesmen, religious leaders, and Ahl al-Bayt, while the graveyard referred to the common men. The funerary architecture was one of the most important Ottoman architectural styles. The locations for the mausoleums in the European cites varied during the Ottoman era [10]. Sometimes, they were found behind the qibla, such as the mausoleum of Rejeb Pasha in Rhodes and the mausoleum of Hasan Bey in Reythmno in Crete island, or in the front of the mosque, e.g. Murad Re'is tomb. Furthermore, the mosque and the mausoleum were often enclosed in a fence to define the facility's campus [11]. Other times, they were located separately from the mosque in the cemeteries. Such styles varied in a way that gave a detailed and comprehensive picture of their features. The Ottoman architect was keen on following the common architectural traditions in Anatolia and Turkey in order not to differ but in terms of the financial and social capabilities of the owner [12]. Furthermore, the religious status of the owner greatly affected the size, pattern, and endowments of the mausoleum. The European lands, including Rhodes, had a local Christian style of funerary architecture. Therefore, the Ottomans did not adopt it as it was particularly related to death. Additionally, the Ottomans adopted many other architectural styles by transforming the churches into mosques, as well as civil or military architecture that the architect could reuse after many modifications to fit the Islamic use. To conclude, the Ottoman funerals in Europe were totally imported.Based on the field study that enlisted the remaining Ottoman mausoleum Rhodes and reviewing some European studies such as Balldutcci [13] and Gabreil [14] on the island's Ottoman architecture and registered many tombs that were removed, many few examples show the features and characteristics of each pattern, they are as follows, fig. (2-b) \& tab. (1) 

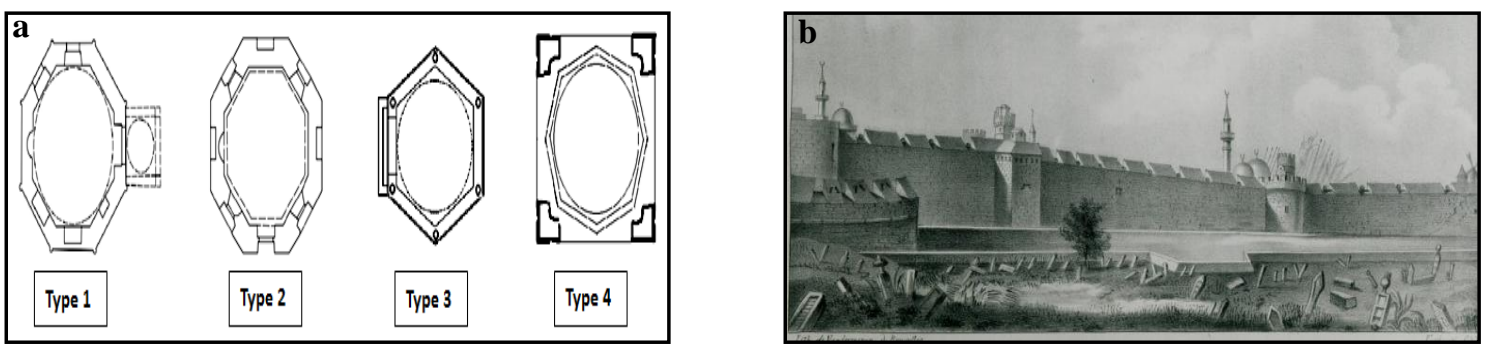

Figure (2) Shows a. the typology of the Ottoman mausoleums in Rhodes Island, $\underline{\mathbf{b}}$. cemetery of martyrs of Muslims in the early $19^{\text {th }}$ century which transformed to Gani Ahmed cemetery

Tab. (1) Lists the types of the Ottoman mausole-ums in Murad Re'is cemetery

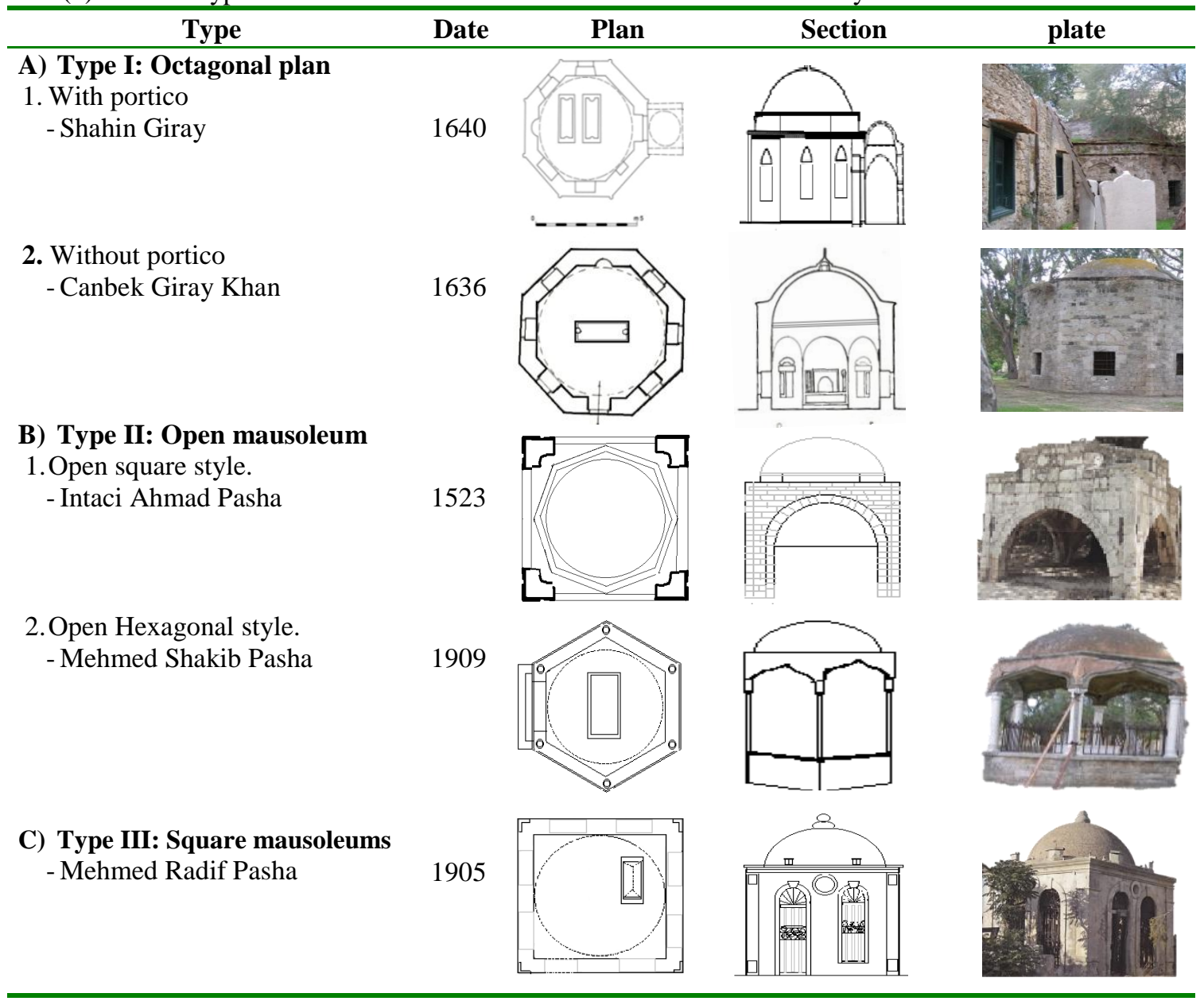

\subsection{Octagonal mausoleums}

\subsubsection{Octagonal mausoleums with a portico at the entrance}

It is an octagonal base with a flap transition zone from external walls of the octagonal base and simple spherical triangles pendentives internally [15]. It bearing pointed section dome, where the outer surface fuses in a plain wrapper following the Ottoman dome in Rhodes. Mimi Pasha mausoleum near Mehmed Radif Pasha's is one of the most significant examples in the cemetery of Murad Re'is, fig s. $(3-a, b)$. It is also known as (Zincirli Dade- Chained Father) that means surrounded by chains because it was surrounded by iron chains. Unfortunately, no inscriptions recording the date of establishment remained, only the gravestone tells that Mimi Pasha passed way in 1620 A.D. The inscriptions show his bravery in the Ottoman fleet's service in the Mediterranean Sea. The plan of the mausoleum is octagonal. Its single entrance is preceded by a square-shaped portico covered with a shallow dome on a transition 
zone of simple spherical triangles pandntivies. The arches are based on a pair of cylindrical stone piers from the northwest side. The three arches are linked with iron tai-beam to increase strength. The southeastern side is based on a side of the mausoleum's octagon. The Turkish Endowment Administration restored the porch in 1958. In the outer sides of the lower octagon, the architect added different stone pillars. He also created a rectangular window opening on each side, except for the southeastern one where the mihrab apse. The marble structure above the mausoleum was in a very poor condition because its northwestern side and the covering marble board fall and they require restoration. This marble structure contains two marble gravestones. It is noted that the gravestones are an integral part of the structure. According to the burial rites, the structure was not correctly placed. Naturally, the head of the deceased and the headstone should be placed in the northwest side facing the footstone. However, the structure's extension is parallel to the qibla wall in the mausoleum. This might be caused by a hasty attempt to combine the structure after falling. The two gravestones are two octagonal marble columns containing the following Arabic inscriptions:

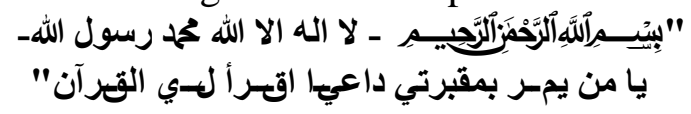

"In the Name of Allah, the Most Beneficent, the Most Merciful- No deity but Allah and Mehmed is His Messenger-O passer-by the grave, pray for me and recite the Holy Qur'an".

The second example; is the mausoleum of Shahin Giray ${ }^{(\mathrm{c})}$ in the cemetery of Murad Re'is directly behind the mosque from the northeastern side. When studying some Turkish buildings in Rhodes, Balducci referred to this grave as Shaheer Giray [13]. According to the inscriptions on the gravestone, it belongs to Shahin Giray (D: 1640) and Fathy Giray $^{(\mathrm{d})}$ (D: 1663) who died at the age of 39 years. Additionally, the inscriptions reveal that Shahin Giray was the son of Crimean Khan Slamat Giray Khan who held many political positions. Later, he was removed from office, exiled, and succeeded by and Sonbol Zadeh Wahbi Efendi in the position of jurisdiction [13].

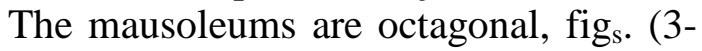
$c, d)$. Its entrance is preceded by a portico of a single tile covered with a dome that has been removed, but the stone links between the mausoleum's wall and the portico accurately indicate the portico. The exterior walls are high and end with an octagonal transition zone, indicating the height of the dome to some extent, if compared to the other mausoleums of the same pattern. Internally, the dome is based on spherical triangles. Additionally, the dome is accessed by a rectangular door opening with pointed arches. There is a window opening on each side of the octagon except for the qibla wall, where the mihrab exists. By entering the dome, there are two marble structures fixed on the gravestones to determine the head crowned with the turban used by the judiciary in the Ottoman Empire and the footstone is a polygon column. On the sides of marble structures, three roses with multiple petals were engraved after the Ottoman marble decorations on fountains and minibars [14]. In the middle of the southeastern side, a semicircular apse ends with a pointed arch. It is smooth and void of decorations. There are many examples outside Rhodes in the same type such as the turbe of Hajji Hamza and Mustafa Baba Dollma in Kruja in Abania [1].

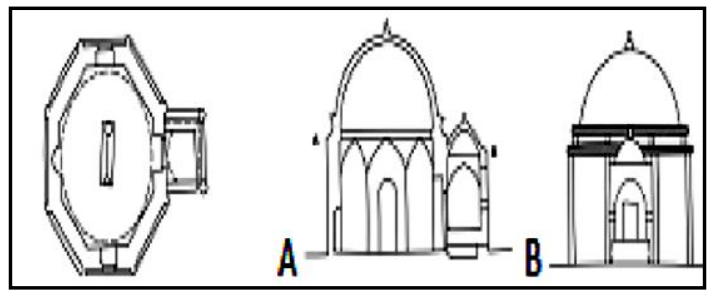

Figure (3-a) Shows plan of Mimi Pasha mausoleum in the cemetery of Murad Re'is, a. crosssection SE-NW, b. an elevation of the northwest façade. (after Balducci, 1932)

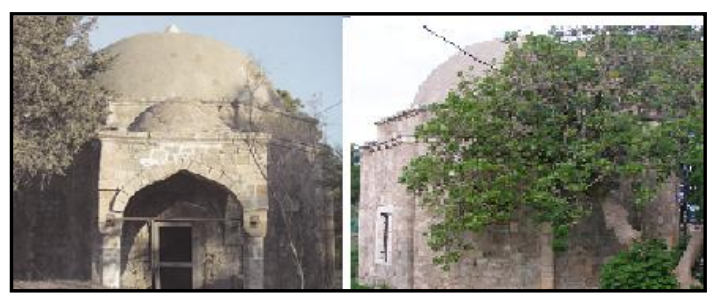

Figure (3-b) Shows Mimi Pasha mausoleum from NW. and SE façades. 


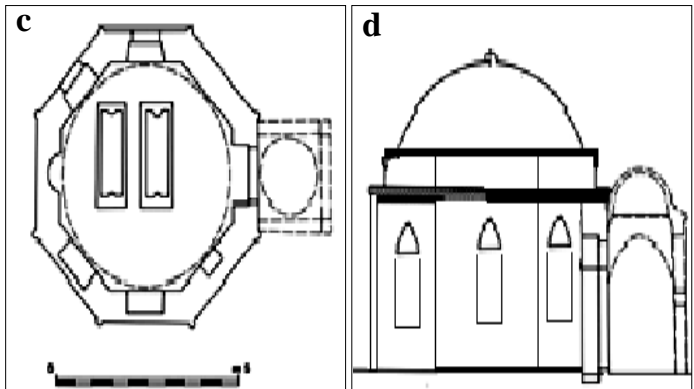

Figure (3) Shows c. the plan and vertical section of Shahin Giray mausoleum, $\underline{\text { d. Shahin }}$ Giray mausoleum

\subsubsection{Octagonal mausoleums without a portico}

The only difference between the models of this pattern and those of the first one is that they do not have a front arcade. Architecturally, they take the form of an octagonal base that is directly followed by a pointed dome based on the walls without a transition zone. Some models are attached to the mosques although the Ottoman architecture in Turkey was not familiar with establishing mausoleums in mosques. Instead, the graves were in cemeteries behind mosques or attached to some charitable facilities in separate buildings [15]. On the contrary, other Islamic regions, e.g. Egypt, were familiar with attaching mausoleums to the religious facilities of the owner or others. The field study revealed that the mausoleum was not established in a certain location in the mosque. It was sometimes behind the qibla wall such as the mausoleum of Rejeb Pasha or in front of the mosque such as Murad Re'is's mausoleum. It is worth noting that the mausoleum was never established inside the mosque, as was the case in the Arab provinces, including Egypt and Syria. In these provinces, the Ottomans adopted the Mamluk traditions by establishing the mausoleum in the most important part of the mosque [16]. Thus, the mausoleums occupied the transitional area of the architectural design. In Turkey and Europe, they were established in cemeteries behind the mosque, e.g. the western cemetery known as Murad Re'is. The models of this pattern date back to the early $15^{\text {th }}$ century. For example, the mausoleum of Sultan
Mehmed I Çelebi that was commissioned before his death in Busra in 1421 AD. It was octagonal and covered with a dome known as the Green Dome. Șehzade Ahmed Çelebi had also a mausoleum in Busra in 1429 AD [1]. Its oldest model was the mausoleum of Murad Re'is (D: 1609 AD) in front of his mosque in the cemetery of Murad Re'is, fig. (4-a) [17]. It was established in $1609 \mathrm{AD}$, while the mosque was established by Abubakr Pasha in 1622-1623 AD to commemorate Murad Re'is [18]. The mosque was renewed by Hasan Bek in 1797-1798. The founding text upon the entrance of the mausoleum displays the date 1276 A.H., fig. (4-b) which is the same date of renewal.

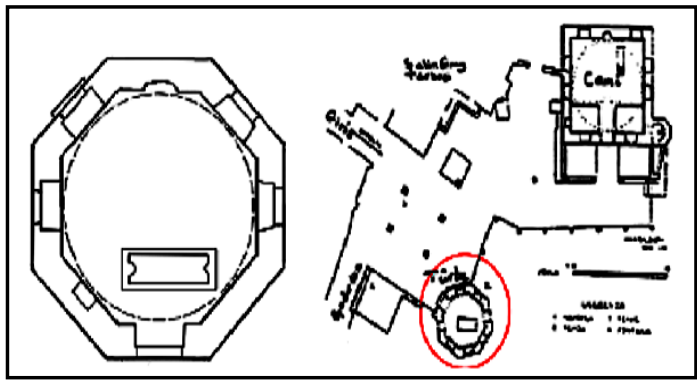

Figure (4-a) Shows the plan of Murad Reis mausoleum and its location in the front courtyard. (after Abdel wahab, 2010)

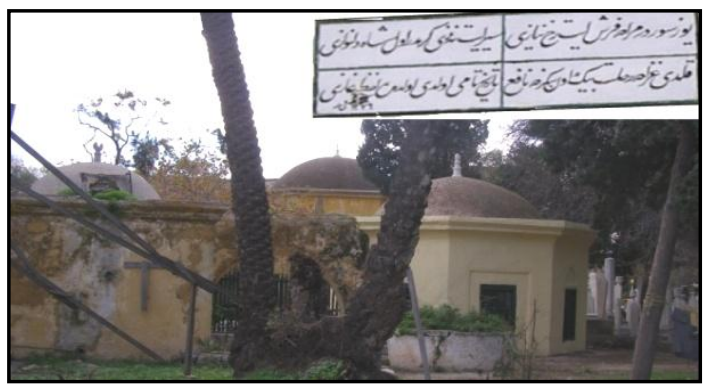

Figure (4-b) Shows Murad Reis tomb from the western-north side and details to the foundation text of Murad Re'is tomb

The Plan of the mausoleum is octagonal. In each side, there is a rectangular window. A semi-circular squinch mediates the qibla wall. On the axis of the mihrab, there is an entrance arched with a triple arch. It is closed with two wooden shutters that resemble the shutters of the front door of Murad Re'is Mosque. A marble stair leads into the entrance to the marble structure that is currently covered with some sheets decorated by the flag of the Ottoman Empire and some Arab and Turkish writings. Notw- 
ithstanding, the walls are decorated with watercolors. Moreover, the transition areas contain circular small windows, where the names of the orthodox caliphs were inscribed in Thuluth. The interest in the cemetery of Murad Re'is reflects his significant position in the Ottoman Empire due to his heroics in commanding the navy in the Mediterranean Sea. As a result, there was an Ottoman naval tradition of firing the navy's mortar when passing by Rhodes to commemorate the leader who was killed while commanding the navy. The mausoleum of Canbek Giray Khan is still good. It lies in the middle of the cemetery of Murad Re'is, fig s. $(4-c, d)$. Canbek Giray was a khan of the Crimean Khnas for two reigns (1610-1623/ 1628-1635). After being unseated from the Crimean in 1634, he was exiled to Rhodes where he died on Sunday corresponding to November 15, 1636 according to the inscriptions on the gravestone. The Turkish traveler Evliya Çelebi indicates these couplets used to take place on the door as follows:

$$
\text { "القادة كالجبال لايصعدون الي السماء" }
$$

"Those lay without a belt, a sword, tied up in the ground".

Today, this inscription does not exist on the tomb. The plan of the mausoleum is octagonal. Except for the qibla wall containing the mihrab, there is a window on each side. The mausoleum is accessed through a rectangular opening with a pointed arch at the top and it is defined by a stone rectangular frame. The windows end with marble lintels with relieving arches at the top. However, the mausoleum is covered with a wretched dome based on spherical triangles and the lower octagon wall. Furthermore, the transition area is never noticed abroad. The ground contains a marble rectangular structure of which the sides are decorated with floral ornaments of multipetal flowers. Moreover, it is framed with a decorative frame of floral and geometric ornaments. All the decorations were implemented in high relief on the marble. Generally, the structure is severely deteriorated. The mausoleum contains many gravestones. While some of them were sca- ttered on the ground, others were randomly fixed beside the structure. This form is incompatible with Ottoman traditions. Fortunately, they still contain the inscriptions on the stone of the main structure that was a simple gravestone topped by a large turban. Some titles, name, and date of death could be observed. For example: grave of Giray Khan son of Haci Salim gravestone with an Ottoman inscription:

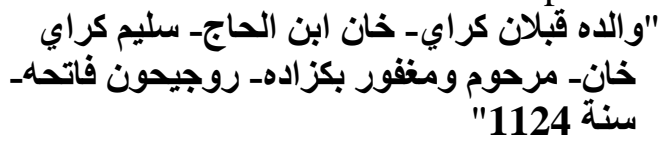

"His Father is Qaplan Giray Khan the son of Haci Salim Giray Khan- the deceased and Forgiven- the Fathih on his soul- Year 1124"

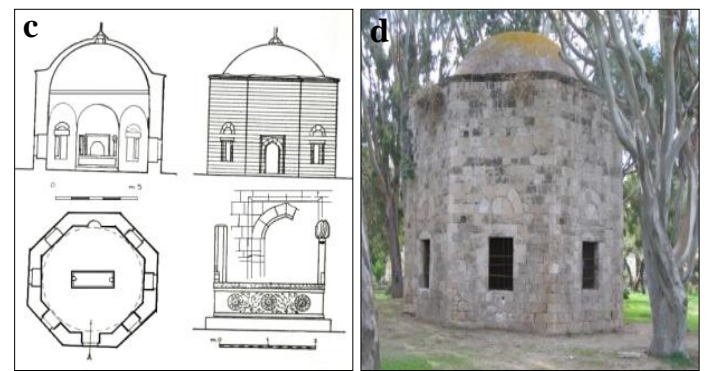

Figure (4) Shows $\underline{\mathbf{c}}$. the plan and sections of Canbek Giray Khan mausoleum. (after Balducci, 1932), d. the mausoleum of Canbek Giray Khan

Another model, but located outside the cemetery, is found in the outer space of Rejeb Pasha Mosque (1588 A.D.) within the old city, fig. (4-e). Remarkable is the location of the mausoleum to the mosque. The architect deliberately chose the location behind the qibla wall. Thus, there could be a kind of visual communication between the prayers and the mausoleum, so they may pray for the deceased. Moreover, the architect asked them to do, as shown in the inscriptions of the fixed gravestone Rejeb Pasha Mausoleum is an octagonal planned. The octagonal transition zone, that has a less diameter, is located outside on the walls. Internally, there are spherical triangles on which the helmet of the laying dome covered with a concrete mixture is based. It is accessed through an opening that has a segmental arch of joggled voissoirs of gray marble, fig. (4-f). Above the opening, there is a hexagonal shutter for ventilation and lighting. The entrance is framed with a double fret 
in the form of a pointed arch. In general, the entrance is a less developed version of the door of Rejeb Pasha Mosque [19].

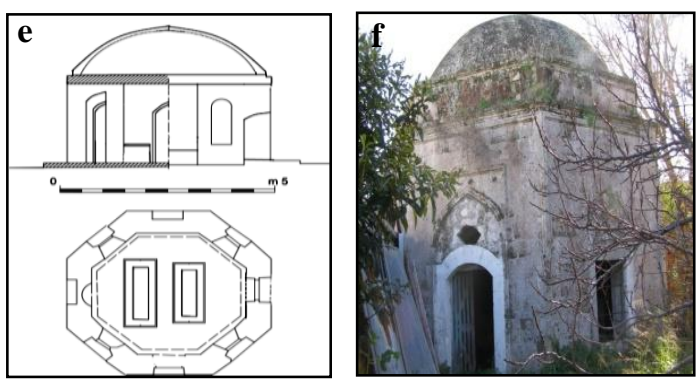

Figure (4) Shows $\underline{\mathbf{e}}$. the section and the plan of Rejeb Pasha mausoleum behind his Mosque inside the fortifications of Rhodes castle (after Balducci, 1932), f. Rejeb Pasha Mausoleum from western- north side

The ground contains two stone structures has marble sides decorated in high relief flowers. Like the Mamluk mosques in Egypt and Syria, the sides of the structure end with a row of triple windows. The inscription on the gravestone states that

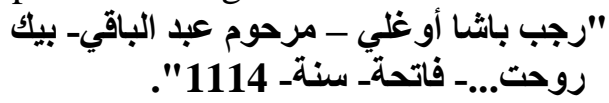

"Rejeb Pasha Oughli- the late AbdulbaqiBey- Fatiha 1114 Year"

The mausoleum of the son of Shah Sultan Hossein was the last Shah of Persia. It represents a significant model of this octagonal style without a front portico, figs. (4-g,h). It is located in the cemetery of Murad Re'is next to the mausoleum of Mohamed Shakib Pasha. According to the inscriptions of the gravestone, it dates back to 1169 H/1756 A.D. It is reported that Shah Safi was a popular and lovable person when he decided to stay in Rhodes. Moreover, he was addressed as a Sultan there [20].

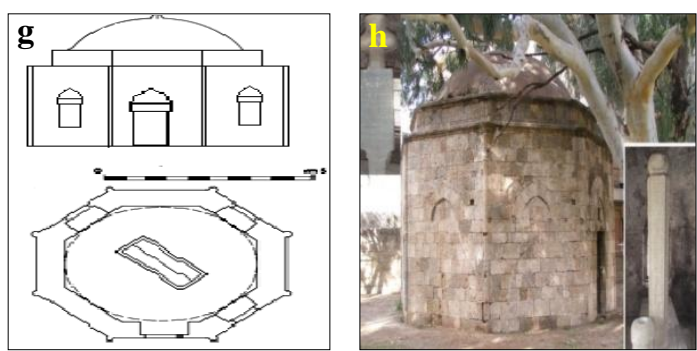

Figure (4) Shows g. section and plan of Shah Safi mausoleum, $\underline{\mathbf{h}}$. Shah Safi mausoleum and the gravestones on his construction
The last model is the mausoleum of Havvas Bey Sencar near the dome of Canbek Giray. The founding inscriptions on the mausoleum shows that it dates back to 1896 A.D./ 1314 A.H. interestingly, the design has evolved as manifested in its structural elements, e.g. the vertical openings in the internal walls, with or without windows, fig. (4-i). Moreover, the dome is higher than the others are. That is, the diameter of the helmet is significantly larger, so the dome is higher than the domes of the civil establishments, fig. (4-j).
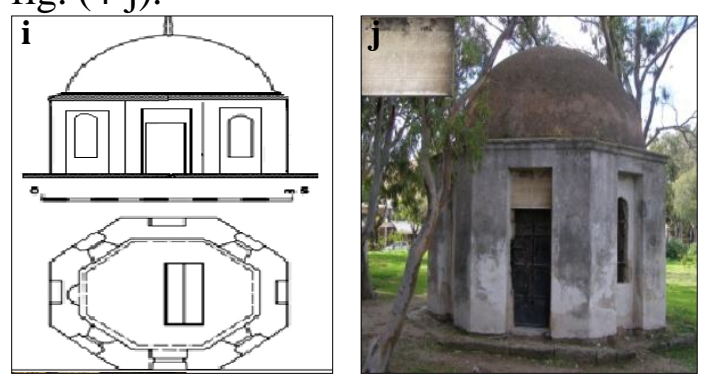

Figure (17) Shows ị. section and plan of Havvas Sencar tomb, $\mathbf{j}$. the mausoleum of Havvas Sencar and the foundation inscription above the entrance

The most significant item is the gravestone. Its model differs from the other traditional ones in the Ottoman mausoleums and tombs of the time in terms of form and content. It takes the form of a five-sided canonical marble stone that covers the top part of the marble structure. In terms of the content, the gravestone is one of the few examples with Arabic calligraphy with Rq`aa, showing the titles, names, and positions of Havvas Sencar:

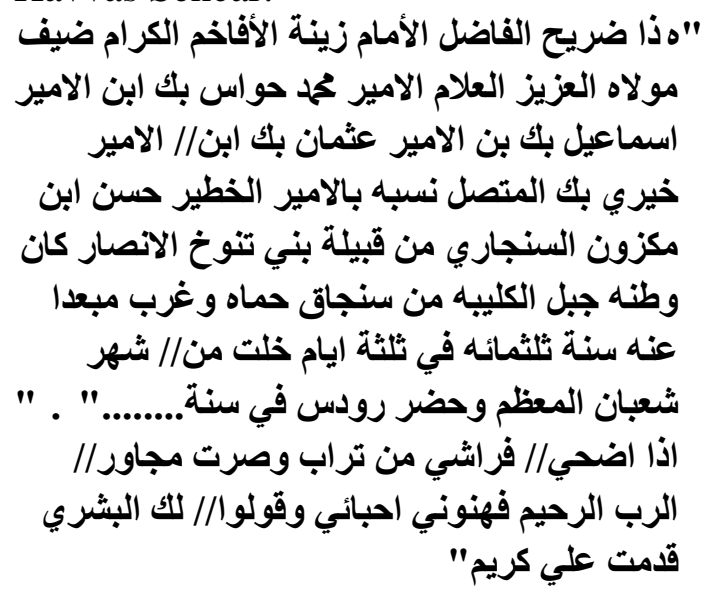

"This mausoleum of the Honorable Imam is the most beautiful of the stately and honored of the honorable guests. His lord is 
the dear scholar Prince Muhammad Hawas Bey Ibn Prince Ismail Bey Ibn Prince Othman Bey Ibn // Prince Khairy Bey, who is related to the dangerous prince Hassan Ibn Mekzoun Al-Sanjari from the tribe of Bani Tanoukh Al-Ansar. Away from his homeland in Alkelayba Mountain of Senjaq, a year three-hundred in three days, which passed from/l the month of Sha'ban, and attended Rhodes in a year ........ ". "If I sacrificel/ my bed from dust and become adjacent to // the merciful Lord, congratulate me my beloved and say// to you, good news that you have come to the generous".

\subsection{Open mausoleums}

They take the form of open graves covered with shallow domes. In Rhodes, there are two models of the pattern.

\subsubsection{Square with four L-shaped piers style}

The plan is square with four L-shaped piers in the angles holding pointed arches. It is topped by an octagonal transition zone similar to the base of the shallow dome covering the lower structure. This architectural pattern was not known but in Anatolia and the other Turkish lands in Asia and Europe. It was not known in other Islamic states, e.g. Egypt and Syria, before the Ottoman era [21]. The piers of this model are directly on the ground or on a stone bench that is not used for burial purposes. Instead, it is upon the tomb. The bench is topped by a marble structure decorated with writing, floral, and geometric motifs, upon which there are two gravestones, i.e. headstone and feet stone. The authors used to call this type open turbe [22]. Its models in Turkey are the clearest example of the architectural development of the second half of the $14^{\text {th }}$ century in terms of open graves covered with a dome on four arches. The oldest examples are the graves of Hajji Hamza- İznik in 1349, Shaheen Pasha-Kirmasti in the late $14^{\text {th }}$ century, and Devlet Shah Khatun the mother of Sultan Galbi Sultan MohamedBursa in 1412 AD [15]. The dome of Intaci Ahmad Pasha the commander of the artillery in the Ottoman army ${ }^{(\mathrm{e})}$. The tomb is taking place outside of the fortress area, where Komninon and Demokratias Streets intersects. It used to take place in the Ottoman Martery cemetery [19]. He led the artillery attack against the fort of Saint John (later known as the Mesdud door), although it is still left, it has experienced a lack of interest and restoration. Moreover, the street level became higher, resulting in the disappearance of the mausoleum's structure. Only the four arches with the transition area appear, fig. (5-a). The higher part of the dome was destroyed, too. The building has experienced landing ground that has caused a remarkable decline in the architectural components. Remarkably, the mausoleum lies outside the city and the grave of the Muslims to the north. The Sultan might insist on burying this martyr to motivate and excite the army to take revenge. This was achieved by invading the entire island in 1523. Despite the poor architectural state, the features of the building could be identified. It is square with square piers of porous sandstone in the four corners because this material was extensively available on the island, fig. (5b). These piers carry four pointed arches topped by two and halves rows of stone courses that, with the arches, form the square base of the mausoleum dome. At this point, the square turns into an octagon, representing the transition area with a minor outside projection to give a room for the dome to cover the entire mausoleum. Unfortunately, nothing was left of the helmet but two incomplete stone courses. The internal part of the transition area consists of four spherical triangles starting from the same transitional area of the four arches.

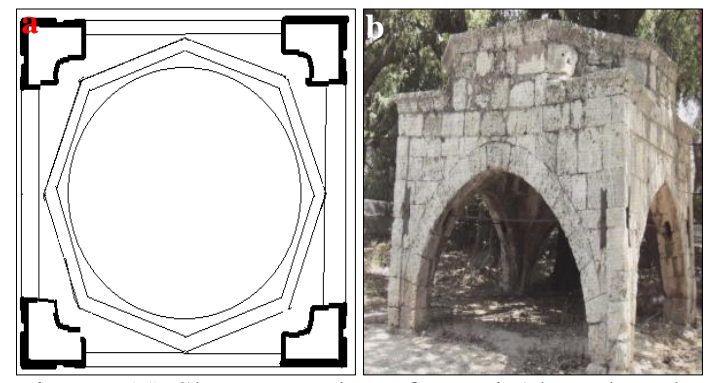

Figure (5) Shows a. plan of Intaci Ahmad Pasha outside of the for tress in the old Ottoman Martry cemetery, $\underline{\mathbf{b}}$. the open mausoleum of intaci Ahmed pasha outside St. Athanasios gate. 


\subsubsection{Hexagonal style}

The plan is hexagonal. In the angels, six cylindrical columns hold an arcade of pointed arches topped by the dome that covers the hexagonal, fig. (6-a). These models represent the last stage of development of the remaining graves in Rhodes. Instead of using L-shaped piers, the architect utilized cylindrical and hexagonal columns in the $18^{\text {th }}$ century. He used to fix them on the angels of the stone bench directly. Similar to the case of the Island's mosques, the columns hold the pointed arches. They are directly topped by a hexagonal base that internally locks the spherical triangles holding the semi-circular helmet. These models were well-known in Turkey, including the mausoleum of Sultan Murad established III the architect Dawood Agha. He covered it with a doubled dome. While the base dome is based on six columns, the outer dome is based on the walls [15]. These models also include the mausoleum behind Defterdar Mosque [4] in Istanbul and the mausoleum of Amna Kadin in 1705 [22]. The mausoleum of Mehmed Shakib Pasha and his wife Aesha Hanim is a unique example, fig. (6-b). He was a governor of Egypt. Later, he was exiled to Rhodes where he and his wife died on the same day in 1909 A.D./1303 A.H. They were both buried in this mausoleum [23].

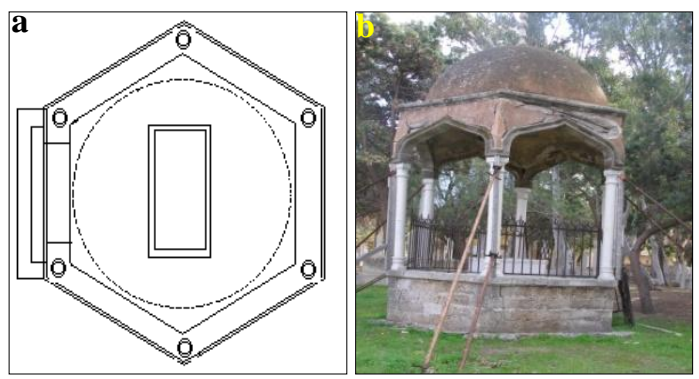

Figure (6) Shows a. the plan of Muhammad Shakib Pasha, $\underline{\mathbf{b}}$. the mausoleum of Muhammad Shakib Pasha and his wife Aisha Hanim

It represents the latest architectural development of mausoleums in the $19^{\text {th }}$ century. Although it is simple and void of decoration, it is highly coherent to seem like a memorial in the cemetery of Murad Re'is, if compared to the surrounding mausoleums. Moreover, it adequately represents the latest develo- pment of this funerary architectural pattern in the Ottoman Empire. Architecturally, it is a hexagonal horizontal projection with walls of $80 \mathrm{~cm}$ high. In other words, the level of the mausoleum is higher than that of the grave. To access the ground, three marble steps were added. They lead directly to the marble structure. The ground is enclosed by an iron fence. In the corners of the hexagonal projection, six columns of white marble with bases and ornate capitals were installed following the Islamic pattern. The bases of the pointed arches are based on the capitals, forming hexagonal arcades with transition areas of spherical triangles. They are topped by a semi-circular base. It is coherent in terms of architectural ratios and general appearance with elegant arches and columns. The dome covers the ground of the mausoleum, enclosing a rectangular marble structure; one side was utilized as a gravestone, containing the titles and names of the deceased. It states:

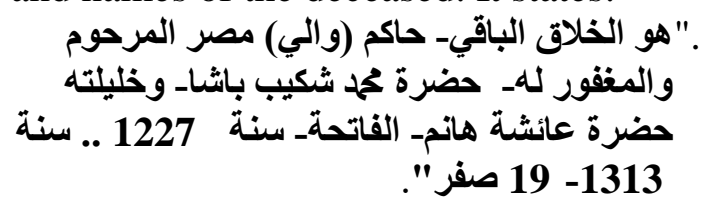

"He is the creator and the everlasting- the ruler of Egypt, the late- his majesty Mehmed Shakib Pasha- and his wife Aisha HanimAlfatiha - Year 1227. Year 1313-19 of Safar".

\subsection{Square mausoleums}

The architectural structure of this pattern is a base square plan. In the middle of each side, there is a window, but the transition area is unclear. The architect employed the enormous thickness of the wall and felt back inside, creating the base of the pointedsection base of the helmet. Its examples include only the mausoleum of Seraskar Mehmed Radif pasha [23] who died in 1905 in Rhodes, he was exiled to the Island after the unsuccessful war with Russia in 1877 [4]. The tomb is in square Plan with a semicircular dome. It was damaged in 1974 [24]. Also, the tomb of "Ǔç Kadinaaít" fig. (7-a) takes a square plan. Except for the northwest side where the entrance opening is located, each side contains a rectangular window. 
Through the spherical triangles, the base square is transferred into a cylindrical base that takes the same level of the walls and on which the semi-circular helmet is based. Moreover, the ground contains three marble structures of different sizes. In the middle, it seems that a child was buried. There are two examples of the same type, i.e. the Hadji Pasha Tomb in Kos Island (935/1556 AD) [24] and the tomb of Sari Askar Muhamed Pasha in Skopje (1323/1905 AD) [25]. The second model of this style is the mau-soleum of Mehmed Radif Pasha, fig. (7-b,c) near Mimi Paha's who was born in Bursa in $1834 \mathrm{AD}$ and died at the age of 70 in 1905 . It was established in 1905. Radif Pasha was born in Bursa and was an Otto-man commander in the Russian war 1877/78 AD. Due to losing a battle, he was dismissed and stayed in the Rhodes until death [4,23]. The development of the Ottoman mausoleums from the first half of the $16^{\text {th }}$ century to the early $20^{\text {th }}$ century can be evaluated in terms of the general layout of the architectural design and doubled window openings with their iron shutters and flying buttresses around the base of the dome. In terms of planning, it is square, on each side; a couple of windows ended with horseshoe arches. An iron shutter closes each of them to firmly close the mausoleum. The architect intended to create a pier with a base and a crown from the wall in the angles to resemble the dominant model of civil architecture in the mid- $19^{\text {th }}$ century in Turkey and Europe. Moreover, the mausoleum is covered with a concrete dome on spherical triangles in the corners of the square base. The internal walls, especially the transition zone, were internally decorated with colorful floral ornaments of branches, small flowers as well as Islamic geometrical design's decorations. The ground of the mausoleum contains a marble structure that has a different design. The upper side is gable and comprises more than a marble piece. Consequently, it differs from the structures of the surrounding mausoleums. On a part of the marble structure, the name, titles, and date of death of Mehmed Radif Pasha were inscribed. The gravestone ends with the Tugh (sharbush) that suggests Pasha title in the Ottoman era. Another example is the mausoleum of Borozany Ali Papa on Omirou St. within the walls of the old city next to the church of Saint Kairakos that was converted into a mosque in $1523 \mathrm{AD}$ [13]. The Ottomans utilized the buildings around the converted church as tekkia named Alagia Tekkia. The mausoleum is dedicated to a great scholar of the Galachnia School, namely Barouzany Ali Papa, who worked as a bugle blower for Sultan Sulayman the magnificent [8]. Barouzany was buried under a stone structure without any gravestones or inscriptions in a rectangular room covered with a simple and flat wooden roof. From the outside, many inscriptions on a marble panel display the date of the tekkia in 920 A.H. and attribute it to Ahmad Pasha who renewed it [26].

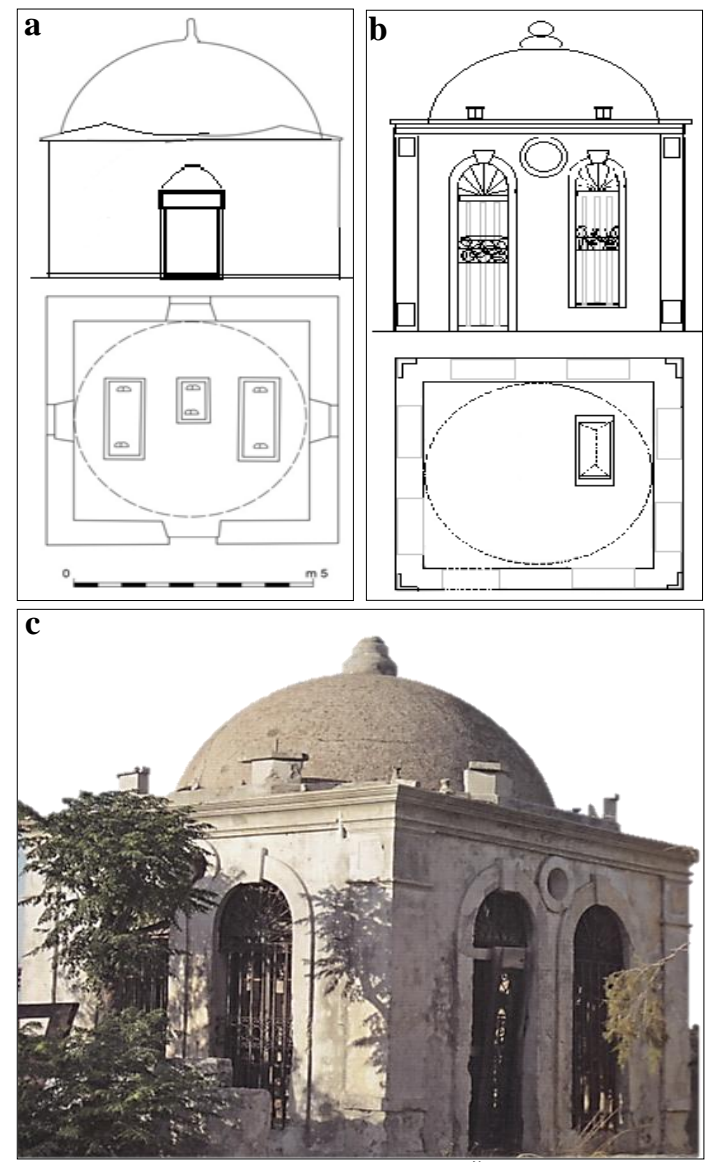

Figure (7) Shows a. the plan of ÜçKadinaaít mausoleum (Baldutcci by the author), $\underline{\mathbf{b}}$. the plan and elevation to the mausoleum of Mehmed Radif Pasha, $\underline{\text { c. the exte- }}$ rnal façades of mausoleum of Mehmed Radif Pasha 


\section{Discussion}

The significant cultural heritage of the Ottoman at the time of leaving Rhodes varies in terms of styles, models, as well as religious, civil, military, social and funeral objectives. They all aimed to achieve the main objective set by the Ottoman decision-makers, i.e. to give the European cities an Islamic and Ottoman character to make the Ottoman pattern prominent in the minds of the local inhabitants. They largely succeeded. The architectural and sometimes administrative imitation of the Ottomans was based on maintaining the status quo while making some functional modifications and changes to the existing establishments. However, this was not the case with the funeral facilities. They were sometimes the final resting place of the owner who found it difficult to make changes to the existing tombs to be Ottomans. Therefore, it is argued that the Ottoman mausoleums in Rhodes are totally Ottoman in terms of form and content. This is applied to all architectural items of the tomb, starting from the construction materials that were prepared for this purpose without recycling any raw or construction materials, as was the case with other establishments by the Ottomans in the European regions they conquered. Based on reading the names and titles on the remaining founding texts or gravestones, the study concluded that from the mid-sixteen century, the cemetery of Murad Re'is was dedicated to the senior statesmen of the military and senior officials. It contained the mausoleums of Murad Re'is the fleet commander and a statesman in Egypt, Canbek Giray Khan (a Crimean), Hvvash Sankar who was originally from HamaSyria, Ahmad Pasha, Radif Pasha, Mehmed Shakib Pasha and his wife, Mimi Pasha Alghazy, and Shah Safi. They mostly held high positions in the army, fleet, or politics in the Ottoman Empire. However, they were removed from office and exiled to Rhodes to be their final resting place. Thus, this cemetery was dedicated to them and their families. Moreover, the remaining Ottoman mausoleums in the cemetery of
Murad Re'is in Rhodes dated back to the first quarter of the sixteen century in 1609 , specifically, the time of establishing the mausoleum of Murad Re'is to the early twenty century (1313 A.H.) when the mausoleum of Mehmed Shakib Pasha was built. The statistical study of the remaining mausoleums in Rhodes illustrated that the architectural patterns differed in terms of design but shared the architectural items and orientation to the southeast by adding the mihrab. The other mausoleums were simple. In many architectural styles as the mausoleums of Mimi Pasha and Shahin Giray in the cemetery of Murad Re'is, the plan was octagonal with a porch in front of the entrance. Additionally, there were many octagonal mausoleums, e.g. the mausoleums of Shah Safy, Rajab Pasha, Havvas Sencar, and Canbek Giray Khan, without a front porch. To conclude, this was the prominent pattern in Rhodes. The study also revealed another pattern, i.e. the open mausoleums, with two models, namely hexagonal open mausoleums such as the mausoleum of Mehmed Shakib Pasha and his wife Aisha Hanim (1901 AD) and open mausoleums with the square projection, e.g. the mausoleum of Ahmad Pasha facing the door of Saint John (the blocked door). The Ottomans adopted the same traditions of Edirne, Istanbul and other large Turkish cities. They were keen on attaching their tombs to charitable and religious facilities in the form of a complex. For example, the mausoleum of Murad Re'is was in a complex containing a mosque, internal and external fountain and an endowed commercial buildings. This complex differs from the other similar ones in Turkey because it was not established by one person. Similarly, the tikke Barozany Ali Baba that contained a square mausoleum, an almshouse for Sufism, a mosque, and a small water tank for the neighboring. The mausoleum of Rejeb Pasha was another example. It was commissioned as a mosque, a fountain to serve the neighboring and a dome behind the qibla wall. These examples suggest the idea of attaching the tombs to the charitable facilities in Rhodes. It is noteworthy that no attempts were made to insert the maus- 
oleums in the main area of the mosque. Rather, they were behind the qibla wall. In other words, they significantly diverged from the eastern Arab provinces in the Mamluk and Ottoman eras. Furthermore, it was noted that many marble gravestones were randomly put in places other than theirs, resulting in many problems with dating and studying when matching their contents to the date of the funeral establishments, especially if they had no founding texts. Consequently, it was extremely difficult to date and accurately attribute the mausoleum.

\section{Conclusion}

The majority of mausoleums in the cemetery of Murad Re'ise belong to people who were Pashas, high official positions and Military men only. But the members of prominent local families and middle class have used the cemetery outside the walls which had transferred to Gani Ahmed cemetery in 1936. Based on the remaining examples of Ottoman mausoleums in Murad Re'is cemetery, it could be said that the funerary architecture was one of the most important Ottoman architecture styles, which were varied to many types in plans. The very common type in the cemetery was the Octagonal mausoleums without a portico. The models of this pattern date back to the early $17^{\text {th }}$ century. For example, the mausoleum of Murad Re'is 1609 AD, The mausoleum of Canbek Giray Khan D. 1635 (1610-1623/1628-1635), Rejeb Pasha 1588 $A D$, The mausoleum of Shah Safi 1756 and the mausoleum of Havvas Bey Sencar 1896 $A D$. Also the cemetery of Murad Re'is contains the octagonal mausoleums with a portico at the entrance, such as the mausoleum of Mimi Pasha 1620 AD. And the mausoleum of Shahin Giray 1640 and Fathy Giray 1663 AD. The Island of Rhodes have a unique style of mausoleums in Greece, it was the open turbe. This type is very rare in Greek lands. This type take the form of open graves covered with shallow domes. In Rhodes, there are two models of the pattern. The most significant example is the mausoleum of Mehmed Shakib Pasha and his wife Aisha Hanim and The open mausoleum of intaci Ahmed pasha. All these types of mausoleums were copied of ottoman examples which separated in many provinces of the empire like Constantinople, Anatoli, Syria and Egypt. In conclusion, I wish that I had succeeded in displaying the architectural and funeral patterns in Rhodes in a way that helps document and date them to maintain them. Furthermore, this paper is a first step to cover all the Ottoman monuments in Europe. The diverse architectural styles of the domes of the shrines in the cemetery of Murad Re'is, include the traditional style with the square layout, the style with the octagonal layout, and the style with the hexagonal layout. The grave tombs of Rhodes include many marble tombstones, which give important information on the owners of the tombs. For example, the tombs of the Crimean Khans document relations with the Ottoman Empire, especially in the periods of the aforementioned Khans, such as Canbek Gira and Shahin Giray. The written inscriptions in the Arabic and Ottoman languages on the domes of the shrine in Rhodes were diverse. They included Qur'anic verses, the Basmalah, the two testimonies, the names of the rightly guided caliphs and supplications, and dates of their death. The paucity of planet motifs and geometry contained in the shrine domes was limited to decorative frames and multi-petal flowers.

\section{Endnotes}

(a) The cemetery of Murad Re'is is located at the bend of the main road leading from Mandraki harbor to the beach outside the old town. The growth of the cemetery dates from the death of Murad Re'is in 1609 A.D. the location have been used as a cemetery before this time because the commanders of Kanuni Suleiman have been buried at this area. Maybe the location had been used as a burial ground for Muslims dating, perhaps, from as early as the Arab conquest in 672-3, undoubtedly the area of Murad Re'is was used as a cemetery from the time of the Ottoman conquest 1522.

(b) The Crimean Khanate originated in the early $15^{\text {th }}$ century when certain clans of the Golden Horde Empire ceased their nomadic life in the Desht-iKipchak (Ukraine and southern Russia) and decided to make Crimea their homeland under their Khan Hac1 Giray (14491466). At that time, the Golden Horde of the Mongol Empire governed the Crimean peninsula as an ulus since 1239 with its capital at Qirim, The Ottomans intervened and brought one of the sons, Meñli I Giray, on the throne. Menli I Giray took the imperial title 
the "Sovereign of Two Continents and Khan of Khans of Two Seas." The decline of the Crimean Khanate was a consequence of the weakening of the Ottoman Empire and a change in the balance of power in Eastern Europe favoring its neighbors. The rule of the last Crimean Khan Şahin Giray was marked with the increasing Russian inf-luence and outbursts of violence from the khan administration towards internal opposition. On 8 April 1783, in viola-tion of the treaty (some parts of which had been already violated by Crimeans and Ottomans), Catherine II intervened in the civil war, de facto annexing the whole peninsula as the Taurida Gov-ernorate. In 1787, Şahin Giray (1777- 1783) took refuge in the Ottoman Empire and was eventually executed, on Rhodes, by the Ottoman authorities for betrayal. The royal Giray family has survived.

(c) There was another Khan under Şahin Giray name. He was born in 1745 in Edirne. In 1776, Şahin Giray succeeded his uncle to become the Khan of Crimea for two reigns; the first from (17771782) and the second from (1782-1783). In 1787, the Ottoman Empire and Russia agreed to allow Şahin Giray to go to Edirne. This action was not the retirement he was expecting because the Ottoman authorities saw him as a potential challenger to the imperial Ottoman throne. He was exiled to Constantinople and then Rhodes where he was executed later that year. He died and buried in his tomb in Rhodes Island in 1787. Thus, he was the last Khan of Crimea on two occasions.

(d) Fetih I Giray (1558-1597, reigned 159697) was briefly the Khan of the Crimean Khanate, interrupting the period of his brother Ğazı II Giray (1588-1607). He was one of the many sons of Devlet I Giray. Khan Adil Giray (1666-1671) was his grandson. When Gazi II became the Khan in 1588, Fetih was appointed
Kalga. In 1592, he led a very successful raid to the south of the Oka River.

(e) Ahmed Pasha the commander of the artillery was a stubborn man. By the conquest of Rhodes, his artillery has attacked the closed gate (Mesdud) and made a gab on the fortress walls but has martyred by the attack and succeeded in opening a large hall in the wall during the Siege of Rhodes (1522-3) led by Sultan Suleiman. Ahmad Pasha was killed and a mausoleum was established in his honor.

\section{References}

[1] Kiel. M., (1990). Ottoman architecture in Albania (1385-1912), Research Centre for Islamic History, Art and Culture, Istanbul.

[2] Çelebi. E., (2009). Siahetnamesi Misr (The travels-Egypt), General Egyptian Book Organization, Cairo.

[3] Inalcik. H., (2001). The Ottoman empire the classics age in 1300-1600, Phoenix, USA.

[4] Barns. J., (2007). The tekye of Murad Re'is on Rhodes: A problem of perc-

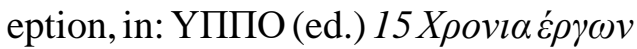

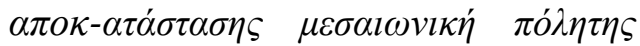

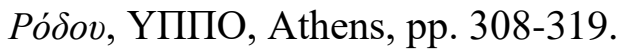

[5] Rodoslu. C., (1945). Rodos ve Istanköy (Rhodes and Kos), Türk Tarih Kurumu Yayinlari, Ankara.

[6] Al-Balazari., (1956). Fattuh al-balad (Conquest of countries), Salah alMunajjid, Dar El-Nahda, Cairo.

[7] Burski. H. (1928). Kemal Re'is: A contribution to the history of the Turkish fleet Bonn Univ. Book Printing Company, Bonn.

[8] Goodwin. G., (1997). A history of Ottoman Architecture, Saqi Books, London.

[9] Rottiers. B. (1828). Discription des monumens de Rhodes, Frechet, Bruxelles.

[10] Abdel Aziz. B., (2007). Islamic architecture in Cyprus, Ph.D., Islamic Archaeology dept., Faculty of Archeology, Cairo Univ. 
[11] Ministry of Culture. (2008). Ottoman architecture in Greece, Livanis pub, Athens.

[12] Pasic. A., (1994). Architecture in Bosnia and Hercegovina, IRCICA, Istanbul.

[13] Balducci, H., (1932). Architettura Turca in Rodi (The Turkish architecture in Rhodes), Ulrico Hoepli, Milano.

[14] Gabriel, A. (1923). La cité de Rhodes, architecture civile et religieuse, (Architecture civile et religieuse), E. de Boccard, Paris.

[15] Aslanapa. O., (1971). Turkish architecture, Faber and Faber, London.

[16] Abdel Wahab. M., (2014). The floral and geometrical elements on the Ottoman Architecture in Rhodes Island, EJARS, Vol. 4 (2), pp. 87-104.

[17] Kuran. C., (1968). The mosque in early Ottoman architecture, University of Chicago press, London.

[18] Hamza. M., (2002). Islamic architecture in Europe, Vol. 1, Kuwait Univ., Kuwait.

[19] Arseven. G., (1935). Les arts decoratifs tures, Milli Egitim. Basimev, Istanbul.

[20] Celikkol. Z., (1992), Rodostaki Turk Eserleri ve Tarihci (Turkish art and historian in Rhodes), $2^{\text {ed }}$, Turk Tarihkurumu Yayinlari, Ankara.

[21] Abdel Wahab. M., (2010). The Ottoman mosques in the old town of Rhodes island, Ph.D., Archaeology and History of Art Dept., Faculty of philosophy, Athens Univ.

[22] Aslanapa. O., (1988). Mimar Sinan in Hayati ve Eserleri (The Life and works of Mimar Sinan), Türk Kültürünü Araştırma Enstitüsü, Ankara.

[23] Kaymakchi. M., (2018). The forgotten Turkish identity of Aegean islands, Egitim Yayinevi, Konya.

[24] Konuk. N., (2008). Ottoman architecture in Lesvos, Rhodes, Chios and Kos islands, Center of strategic research, Istanbul.

[25] Hillenbrand. R., (1994). Islamic architecture, Edinburgh Univ. Press, Edinburgh.

[26] Pitsinos. N., (2008). The complex of Aghia Kyriaki in the medieval town of Rhodes, in: ҮППО (ed.) 15

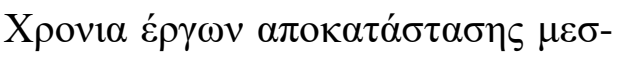

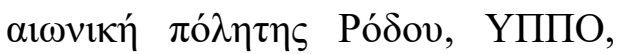
Athens, pp. 128-139.

[27] Mikhail Kizilov. M., (2007). Slave trade in the early modern Crimea from the perspective of Christian, Muslim, and Jewish, J. of Early Modern History, Vol. 11 (1), pp. 1-31.

[28] Fisher. A., (1998), Between Russians, Ottomans and Turks: Crimea and Crimean Tatars, Isis press, Istanbul. 